NBER WORKING PAPER SERIES

\title{
FINANCE AS A BARRIER TO ENTRY: BANK COMPETITION AND INDUSTRY STRUCTURE IN LOCAL U.S. MARKETS
}

\author{
Nicola Cetorelli \\ Philip E. Strahan \\ Working Paper 10832 \\ http://www.nber.org/papers/w10832
NATIONAL BUREAU OF ECONOMIC RESEARCH
1050 Massachusetts Avenue
Cambridge, MA 02138
October 2004

Cetorelli is at the Federal Reserve Bank of New York. Strahan is at Boston College and the NBER. Most of the work was done while the first author was at the Federal Reserve Bank of Chicago. The views expressed herein are those of the authors and not necessarily those of the Federal Reserve Banks of Chicago, New York or the Federal Reserve System. We thank an anonymous referee for very helpful comments. We also thank for their inputs Jeremy Stein, Luigi Zingales and seminar participants at Boston College, the Federal Reserve Banks of Chicago and New York, Ente Einaudi, Wesleyan University and UC Davis. The views expressed herein are those of the author(s) and not necessarily those of the National Bureau of Economic Research.

(O2004 by Nicola Cetorelli and Philip E. Strahan. All rights reserved. Short sections of text, not to exceed two paragraphs, may be quoted without explicit permission provided that full credit, including $\odot$ notice, is given to the source. 
Finance as a Barrier to Entry: Bank Competition and Industry Structure in Local U.S. Markets Philip E. Strahan and Nicola Cetorelli

NBER Working Paper No. 10832

October 2004

JEL No. G2

\section{$\underline{\text { ABSTRACT }}$}

This paper tests how competition in local U.S. banking markets affects the market structure of nonfinancial sectors. Theory offers competing hypotheses about how competition ought to influence firm entry and access to bank credit by mature firms. The empirical evidence, however, strongly supports the idea that in markets with concentrated banking, potential entrants face greater difficulty gaining access to credit than in markets where banking is more competitive.

Nicola Cetorelli

Federal Reserve Bank of New York

nicola.cetorelli@ny.frb.org

Philip E. Strahan

Carroll School of Management

324B Fulton Hall

Boston College

Chestnut Hill, MA 02467

and NBER 
Economic research has focused intensely in recent years on the role played by financial markets for real economic activity. Scholars have provided robust empirical evidence that broader, deeper financial markets are strongly associated, causally, with better prospects for future economic growth. ${ }^{1}$

Having established this basic finding, the research effort is now focused on the analysis of the mechanisms through which finance affects real economic activity. What are the specific characteristics of financial markets that seem to affect firms and industries in non-financial sectors of production? $?^{2}$ And, what specific characteristics of firms and industries are especially affected by finance so that it eventually translates into higher economic activity? So, for example, does it matter who receives credit in an industry? Entrants? Incumbent firms? Is it the same if an industry has a few large firms, or whether instead entry always brings in younger, smaller firms?

This paper goes straight to the heart of this line of research by investigating the role of well-defined characteristics of banking markets on equally well-defined characteristics in product markets. More precisely, we investigate the impact of bank concentration and bank deregulation on measures of industry structure in non-financial sectors. We ask whether concentration of market power in banking has an effect on the number of firms in a given sector, on firms' average size, and on the overall firm-size distribution.

\footnotetext{
${ }^{1}$ This work is based on ideas tracing back at least to Schumpeter (1912), and inspired by the early contributions of Goldsmith (1969), Gurley and Shaw (1955), and McKinnon (1973). Among the most recent contributors, we cite the work of King and Levine (1993 a,b), Demirguc-Kunt and Maksimovic (1998), Levine and Zervos (1998), Rajan and Zingales (1998), Levine, Loayza and Beck (2000), among many others.

${ }^{2}$ For example, La Porta, Lopez-de-Silanes and Shleifer (2002) have investigated the role of government ownership in banking; Levine (1999) has focused on the importance of the quality of legal protection of creditor rights;
} 
The number of firms in a sector, average firm size and the composition between small and large firms are all important factors having a bearing on conduct and market performance. Such factors are therefore important determinants of a sector's capital accumulation and consequently of its contribution to overall economic growth. Seeking evidence of a link with specific characteristics of the banking industry thus brings the focus of analysis exactly on the question of how finance affects real economic activity.

Using data on U.S. local markets for banking and non-financial sectors, we find that more vigorous banking competition - that is, lower concentration and looser restrictions on geographical expansion - is associated with more firms in operation and with a smaller average firm size. In fact, we find that the share of firms in the smallest size category (fewer than five employees) increases most dramatically with better bank competition, mostly at the expense of firms with between 100 and 1,000 employees. We find no effect of changes in banking competition, however, for the largest firms, which seems sensible given that these firms generally have access to nationwide securities markets.

Whether bank competition is "good or bad" for economic activity has been and continues to be a lively topic of research and policy analysis. ${ }^{3}$ In addition to the conventional argument that concentration of market power in banking means lower equilibrium amounts of credit, it has also been claimed that banking market power is actually needed for banks to establish valuable lending relationships. Hence, whether more or less competition in banking is socially desirable

Jayaratne and Strahan (1996) and Cetorelli and Gambera (2001) have instead explored the role of bank competition on firms' growth performance.

${ }^{3}$ A conference titled "Bank Competition: Good or Bad?" was organized in 2000 by The Wharton School and the Center for Financial Studies at Frankfurt University. More recently, two conferences on the role of bank concentration and competition have been organized by the World Bank and by the Cleveland Fed-JMCB. 
is still under discussion. This paper thus contributes to expand our understanding of the economic role of bank concentration and competition.

Various related streams of literature have focused on determinants of product market competition (e.g., Brander and Lewis (1986), Chevalier (1995), Kovenock and Phillips (1995, 1997), Maksimovic (1988)), on firm size (e.g., Kumar, Rajan and Zingales (2001), Campbell and Hopenhayn (2002)) and on firm-size distribution and more general industry dynamics (e.g., Lucas (1978), Jovanovic, (1982), Evans (1987), Hopenhayn (1992)). This paper relates to these parallel lines of research and makes a contribution bridging them together.

Our evidence is consistent with that documented in several recent papers focusing on banking concentration and competition policies across countries. Cetorelli (2001) provides evidence of larger average firm size in countries with more concentrated banking. Along similar lines, Cetorelli (2004) finds that enhanced bank competition following passage of the Second European Banking Directive brought a reduction in average firm size. Matching data on job creation and destruction in US manufacturing sectors with banking data across US markets, Cetorelli (2003) shows that more bank concentration implies less entry and thriving of younger firms and also delayed exit of older firms. Again based on cross-country data, Beck, DemirgucKunt and Maksimovic (2004) find that higher bank concentration is associated with more financing obstacles, especially for smaller firms. Bertrand, Schoar and Thesmar (2004) find evidence that bank deregulation in France led to more entry in bank-dependent sectors of production. Exploiting historical census data from nineteenth century Mexico, Maurer and Haber (2003), find evidence that bank concentration favored lending to "connected" borrowers in the domestic textile industry over other competitors, even though these last ones exhibited 
higher efficiency measures. In contrast, Bonaccorsi and Dell'Arriccia (2004) find that

concentration in banking reduces entry rates for Italian firms in industries with relatively opaque assets (i.e. few intangible assets) relative to entry in industries with less asset opacity.

Ours is the first study to explore not only how average firm size responds to banking competition, but how the whole size distribution responds. This is an important improvement, in that we are able to test more directly whether more or less bank competition is beneficial for all firms in a sector, or whether instead the effect may be different for firms in distinct size classes. The analysis on the size distribution will also allow us to characterize more fully results obtained so far in the literature on average size: if indeed changes in bank competition have an impact on the average firm, we will be able to tell whether the effect is mainly on the smaller firms or on the larger ones or both. Moreover, our data allow us to measure banking structure at a more local level. This is a distinct advantage because much of the research on bank market power suggests that the relevant geographical market for banking services, especially for small firms or potential entrepreneurs, is local (see, for example, Berger, Demsetz and Strahan, 1999).

In the remainder of the paper we first flesh out the theoretical links between banking concentration and industrial structure in order to motivate our empirical tests. In Section II we discuss our identification strategy, while in Section III we present the data set and the main variables used in the analysis. Section IV documents the empirical results, and Section V concludes.

\section{Theoretical arguments}

How does bank competition affect the market structure of non-financial industries? As pointed out in Cetorelli (2001), several countervailing forces are potentially in play. One force 
emphasizes that lending to opaque firms requires the bank and the borrower to forge a long-term relationship. Information gained over the course of time by the bank can be used to make valueenhancing credit decisions (i.e. expand credit to "winners" and restrict credit to "losers"). Banks can sustain the cost of starting a relationship with unknown, risky entrepreneurs, however, only if market power allows them to recoup the cost at later stages if such entrants turn out to be successful. This is an idea first presented by Mayer (1988) and then formalized and tested by Petersen and Rajan (1995). ${ }^{4}$ To the extent that it forecloses the opportunity to extract profits from successful relationships, vigorous competition may mitigate banks' willingness to invest in relationships at all. This force, applied to our case, suggests that banks with market power should guarantee more industry entry than competitive banks would. At the same time, because banks with market power charge higher rates to the older firms than competitive banks would, firms in non-competitive banking markets may not grow as large as they could otherwise. All together, and ceteris paribus, one should expect to find more firms in an industry, a lower average firm size, and a larger prevalence of small rather than large firms where banks have more market power.

Two countervailing forces suggest that market power may both dampen entry and reduce the relative importance of smaller firms. First, bank market power may reduce credit availability generally. This standard channel, whereby increased concentration in banking leads to less credit supply and higher loan prices, justifies antitrust enforcement. While less credit hurts all firms, smaller firms and potential entrants are likely to be more reliant on bank credit than larger

\footnotetext{
${ }^{4}$ Another solution is for the lender to hold an equity, or equity-like, claim against the establishment, as is commonly observed in the venture capital industry.
} 
and better established firms. Thus, these smaller firms may be harmed more by reduced credit supply than larger firms.

In addition to this standard channel, banks with market power may tend to favor their established borrowers over new borrowers. The value of a bank's current lending relationships will depend on its borrowers' future profitability, which in turn depends on prospective entry and growth of new competitors. A bank's incentive to support the profitability of its older clients could thus restrain its willingness to extend credit to potential industry entrants (or emerging small firms). In recent papers, Spagnolo (2000) and Cestone and White (2003) have presented theoretical frameworks in which existing lending relationships do indeed affect the behavior of lenders vis-à-vis potential new borrowers. ${ }^{5}$ The less competitive the conditions in the credit market, the lower the incentive for lenders to finance newcomers. Hence, banking concentration (as well as regulatory impediments to competition) can represent a form of financial barrier to entry in product markets. Banking market power may lead to fewer firms, a larger average firm size, and a higher proportion of large firms in markets where banks have more market power. ${ }^{6}$

\section{Identification strategy}

These ideas suggest that banking competition potentially plays a key role in determining industry structure in product markets. Either prospective entrants benefit at the expense of older incumbents with more bank competition, or the other way around.

The difficulty in empirical implementation is that there may be common factors that drive the structure of both banking and industrial sectors that are difficult to measure and thus control

\footnotetext{
${ }^{5}$ Also related are the contributions of Battacharya and Chiesa (1995) and Helmann and Da Rin (2002).

${ }^{6}$ This effect should be especially strong where the boundaries of product markets and lending markets coincide.

Some product markets in our dataset may span multiple banking markets. In such cases, a bank could still have an
} 
in a regression. For example, small markets may have fewer banks and also fewer non-financial firms. Finding a positive association between bank concentration and product market concentration could simply pick up this market characteristic. By the same token, banks have increasingly turned to analytical credit scoring models based on systematic statistical processing of information about borrower credit history, financial strength, and asset values. This growing importance of "hard information" may have led to a corresponding decline in the value of lending relationships over time. If technology adoption (which is difficult to measure empirically) exerts an independent effect on the structure of both banking and non-financial industry, then our ability to sort out how bank concentration affects industry structure may be confounded. $^{7}$

Given these concerns, identification based on direct effects of changes in bank competition across industries in a market will not take us far. We proceed instead with the idea that banks play a more important role for firms in some industries than in others. Rajan and Zingales (1998) point out that industries differ in their dependence on external sources of finance. These differences stem from industry-specific technological reasons affecting the initial project scale, the gestation period, the cash-harvest period, and the needs for further investments (Rajan and Zingales, 1998, p. 563). So, for example, a firm in a sector such as Tobacco or Leather is less likely to depend on external sources of finance (such as bank lending) than firms producing Electronics or Chemical equipment.

impact on entry within her area of influence. But because we are unable to define product market boundaries, our results are, if anything, biased toward a non-result.

${ }^{7}$ Information technology may also have played a role in explaining deregulation of banking, although Kroszner and Strahan (1999) find that the strength of interest groups can explain the precise timing of deregulation across states. 
Given the richness of our data set (to be illustrated in the next section), we pursue identification by exploiting cross-industry differences in external financial dependence. Firms in sectors more dependent on external finance ought to be affected more by variation (both across time and across markets) in bank competition. More precisely, we use non-dependent sectors as a control group, which in an 'experiment' designed to gauge the effect of a change in bank competition is not expected to exhibit a response. We can instead use dependent sectors as a treatment group that in the same experiment are expected to exhibit a response. We thus achieve identification by measuring the differential effect of a change in bank competition between the two groups. So, going back to the first of our previous examples, if none of the theoretical arguments presented earlier bear any justification in the data, and if market size is all there is behind a positive correlation between bank concentration and product market structure, then a change in bank competition should not have any differential effect between treatment and control groups. But if, say, bank competition actually implies greater opportunities for entry, then such effects should be larger on the treatment sectors.

We implement this strategy by estimating regression models fitting into the following general structure:

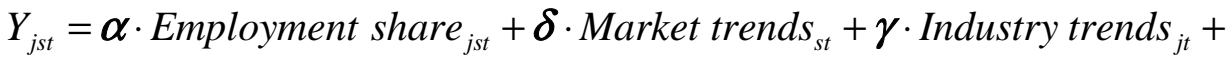

$$
\begin{aligned}
& +\beta \cdot \text { Bank dependence }_{j} \cdot \text { Bank competition }_{s t}+\varepsilon_{j s t},
\end{aligned}
$$

where in separate regressions $Y$ will equal the number of firms, average firm size, or a measure of the entire size distribution of industry sector $j$ in market $s$ over time $t$. The industry $j$ share of total manufacturing employment in market $s$ over time $t$ controls for the relative importance of a 
given sector in a market. ${ }^{8}$ The Market trends $s_{s t}$ are vectors of market/time indicator variables controlling for any local market, time-varying effect on industry structure. Similarly, Industry trends $_{j t}$ are industry/time indicator variables controlling for industry-specific, time-varying factors. By including the two sets of fixed effects, we fully absorb any common confounding factor that could trouble identification, thereby minimizing the risk that our results will be driven by either reverse causality (changes in industry structure driving changes in banking structure), or by an omitted factor (e.g. technological changes that drive both banking structure or regulations and the structure of non-financial businesses). Consistent with the identification strategy, note that the direct effect of bank dependence is not identified because its effects are fully captured by the set of industry-level fixed effects. Similarly, the direct effect of bank competition is also not identified; its effects are fully captured by the market-level fixed effects.

The coefficients of interest, which measure the effect of bank competition, are identified by estimating a vector of three separate interaction terms between an industry-specific external bank dependence measures with three alternative measures of bank competition (described below). For instance, consider a regression where the dependent variable is a measure of the number of firms in operation in each industry. If an increase in bank competition facilitates entry, then this increase in the number of firms should be especially pronounced for sectors with a high degree of bank dependence. Thus, the interaction of bank dependence with bank

\footnotetext{
${ }^{8}$ In studies of cross-sector industrial growth, such a measure consistently predicts that sectors that had grown substantially in the past, and therefore are already relatively large, grow less in the future (see Rajan and Zingales, 1998 and Cetorelli and Gambera, 2001). Moreover, theories of an industry's life-cycle predict that a sector that has already grown substantially should experience less intensive firm entry (see Klepper, 1996). Hence, the share variable controls for the stage in industry life-cycle a sector is in, and specifically it should capture the different intensity in entry due to life-cycle specific reasons.
} 
competition will be positive and significant. The opposite would be true if entry were more likely where banks have market power.

\section{Variable Definitions and Data Sources}

We have constructed a panel data set of manufacturing establishments in operation across U.S. states between 1977 and $1994 .{ }^{9}$ Data on establishments are available at a disaggregated level on an annual basis from the County Business Patterns, which is an annual survey by the Census Bureau. These data provide the best way to consider industry structure over a long span of time at a disaggregated level. Moving to a more finely disaggregated level, either by industry SIC code or by locality, creates substantial difficulties with missing values, so we have decided to focus on the 2-digit level of aggregation by industry and the state level for geography. We focus on just industries within the manufacturing sector. From this data set, we compute the total number of establishments in an industry/state/year, and the average establishment size (workers per establishment). As shown in Table I, there are, on average, 0.07 establishments per capita, and the average establishment has 69 workers.

\section{TABLE I ABOUT HERE}

To characterize the whole distribution of establishment sizes, we construct the share of establishments in an industry, state and year in each of four categories: establishments with fewer than five employees, establishments with five to 19 employees, establishments with 20 to 99 employees, establishments with 100 to 999 employees, and establishments with 1,000 or more employees. Unconditionally, 31 percent of establishments are in the smallest size category, 
while 86 percent of establishments have fewer than 100 employees (Table I).

Before moving forward, it is worth noting that our data are based on employment at establishments rather than at firms. An establishment is an economic unit where production occurs, such as a plant, a factory, or a restaurant that employs people. So, there is some measurement error in our dependent variable induced by the fact that large firms often own many establishments. Data from The Economic Census, however, suggest that most firms are composed of just one establishment. For example, in 1997 there were a total of 316,952 manufacturing companies; of these, 295,876 were single-establishment companies, about 94\% of the total. Also, at the same time there were a total of 381,696 establishments in operation. So, single-establishment companies represented $78 \%$ of total establishments. ${ }^{10}$

\section{A. Constructing an instrument for bank dependence}

As we discussed in the previous section, the effects of banking competition on industry structure ought to depend on the relative bank dependence of firms in an industry. The trick empirically is to construct a measure of bank dependence that reflects demand for bank finance, rather than one that confounds demand-side effects with variation in the availability of credit supply from banks. ${ }^{11}$ As indicated by the summary statistics for establishments, most firms are small. Moreover, the theoretical arguments illustrated earlier all emphasize the role of banks for small firms and potential entrants. We thus began by constructing a measure of bank finance

\footnotetext{
${ }^{9}$ The choice for the sample period is justified later on in this section, when we describe the history of deregulation of the U.S. banking industry.

10 These proportions are similar looking back at previous Census data. Early research has also shown that, for example, the rate of creation of new businesses is correlated with the share of new establishments in a local economy (Black \& Strahan, 2002). The existence of a close correlation between the number of establishments and the number of firms is also documented in Cetorelli (2001) for a cross-section of countries.

${ }^{11}$ Variation in bank credit supply introduces noise (measurement error) into the actual use by small firms of bank finance. Moreover, the extent of that noise will be greater for firms in industries that are more bank dependent.
} 
using data from the 1998 Survey of Small Business Finance. This survey was conducted by the Federal Reserve and covers a sample of 3,561 small firms with fewer than 500 employees. The sample was designed to be nationally representative, but was structured to ensure representation across firm-size categories, location, and race of the owner. For each 2-digit SIC manufacturing sector, we constructed firms' share of assets financed with debt (loans, capital leases and lines of credit) from financial institutions ("loans") for the firm at the median of the distribution. These loans are supplied mainly by commercial banks ( $70 \%$ of the surveyed firms use banks for credit), but they also include some funds from other depository institutions (thrifts, credit unions) as well as unregulated finance companies (Bitler, Robb and Wolken, 2001). This variable represents the actual use of bank finance by small firms, as a share of their balance sheet. ${ }^{12}$

Despite the appeal of such measure to capture firms' need for bank finance, the very fact that the data is based on small firms, with relatively limited access to external suppliers of finance, raises the possibility that such accounting measures could not be clean measures of demand. We therefore proceed by constructing an instrument for bank dependence using information from Compustat firms and justify that choice by documenting its high correlation with small firms' actual use of bank (and other intermediary) funds. Our procedure follows closely the one described in Rajan and Zingales (1998). The key identifying assumption, as in Rajan and Zingales, is that the use of finance by Compustat firms allows us to observe their demand for external funds. These firms are large and well established, with far better access to well-developed U.S. securities markets than small firms. Hence, there is a much higher likelihood that observed financial policy is not skewed by constraints on the supply side.

\footnotetext{
${ }^{12}$ The Survey of Small Business Finance only reports data for a single year, hence balance sheet measures are more
} 
We begin by taking all of the Compustat firms between 1980 and 1997 and carefully separate firms based on the number of years they have been on Compustat. More precisely, we exclude "young" Compustat firms, i.e. firms that had gone public only recently. A measure of external financial dependence for such firms is likely to be non-representative of the typical needs of a firm in a given sector due to selection bias: firms that have just gone public have a voracious appetite for external funds - satisfying this high demand is a large reason that they went public in the first place. Following Rajan and Zingales (1998), we define as "young" those firms in Compustat for 10 years or less, and we define as "mature" those firms appearing in Compustat for more than 10 years. ${ }^{13}$

To construct external financial dependence, we sum across all years each firm's total capital expenditures (Compustat item \#128) minus cash flow from operations. Cash flows from operations equals revenues minus non-depreciation costs (Compustat item \#110) plus decreases in inventories and accounts receivable plus increases in accounts payable. ${ }^{14}$ This sum equals the total external funds needed to finance investments. If the total is negative, it means the firm had free cash flow available for disbursement to shareholders or to pay down debt; otherwise, the firm needed to raise additional capital to finance its investment. We then divide this free cash

\footnotetext{
representative of financial policy than flow-based measures using capital expenditures and gross cash flow.

${ }^{13}$ We have also changed the cut off point to 5 years instead of 10 . The resulting new measure of external financial dependence for "mature" firms had a correlation of 0.98 with that used following Rajan and Zingales. The regression results we present later on were not qualitatively affected by the choice of this alternative definition of mature firms.

${ }^{14}$ In other words, we subtract investments in net working capital from cash flow. The numerator of external financial dependence equals the negative of "free cash flow" as traditionally defined in capital budgeting problems. We have also constructed an external financial dependence measure that normalizes this figure by net long-term investment (capital expenditures minus depreciation) and also by net total investment (i.e. capital expenditure minus depreciation plus the change in net working capital). These measures are highly correlated with the one used here ( $\rho=0.89$ and $\rho=0.70$, respectively). Note also that the Compustat items mentioned in the text are only defined for cash flow statements with codes 1, 2 or 3. For format code 7, we use the sum of items \#123, 125, 126, 106, 213 and 217.
} 
flow figure by total capital expenditure. After constructing this ratio for each firm, we use the median value for all firms in each 2-digit SIC category.

Table II reports our measures of external financial dependence for mature Compustat firms and that calculated from the 1998 Survey of Small Business Finance. Looking across sectors, we find that leather and leather products, tobacco manufactures and apparel have the lowest need for external funds as mature firms, whereas electronic equipment and chemicals and related products exhibit the highest need for external finance. Moreover, the correlation between the two measures of external financial dependence is high $(\rho=0.51)$, thus suggesting that external financial dependence for mature Compustat firms makes a powerful instrument for small firms' demand for bank credit.

\section{TABLE II ABOUT HERE}

As described in the previous section, we want to emphasize the distinction between lowdependent sectors (the control group) and high-dependent ones (the treatment group). Hence, we use an indicator variable for a firm's external financial dependence in our base specification equal to one if the use of external funds for mature Compustat firms is positive and zero otherwise. Beyond permitting a clean interpretation of the results, the indicator for external financial dependence will not be skewed by the very high level of cash flow relative to investment for three sectors - Leather, Tobacco and Apparel - documented in Table II. For robustness, however, we also report results using the continuous measure of external financial dependence for mature Compustat firms (rather than a zero-one indicator variable), as well as the 
loans-to-assets ratio for small firms. ${ }^{15}$

Table III compares investment and financing behavior for Compustat firms by our measure of external financial dependence. These simple comparisons show that differences in external financial dependence are not correlated with differences in investment rates, market valuation, or size. For both groups, for example, the investment rate (capital expenditures divided by / property, plant \& equipment), the book-to-market equity ratio, and real sales are approximately equal. Also, external funds - for those firms that continue to need them - are raised mostly by borrowing; the median mature firm uses no equity to finance new projects. Thus, the greater demand for external finance at mature firms does not seem to reflect greater growth or investment opportunities; instead, as suggested by Rajan and Zingales, external finance reflects differences in the incubation period before assets begin to generate sufficient cash to finance the firm. Thus, we can be confident that differences in response to bank competition across these two groups of industries reflect difference in their financing needs, rather than differences in their real investment behavior. ${ }^{16}$

\section{TABLE III ABOUT HERE}

\section{B. Competition in the local banking market}

We focus on several measures of competition in the local banking industry. Our first two measures exploit policy innovations. Restrictions on bank expansion across geographical

\footnotetext{
${ }^{15}$ While mature firms in Compustat clearly have access to alternative sources of finance beyond banks (e.g. bonds or public equity), our identifying assumption is that demand for external credit for small and medium-sized firms will look similar to demand for external funds by mature Compustat firms. Since smaller firms do not have access to public securities markets, we argue that their ability to raise external funds will depend critically on the competitiveness of the local banking market.

${ }^{16}$ Implicit in our identification strategy is the assumption that external financial dependence is constant over time, or at least that the industry ordering is not altered substantially. Since we compute external financial dependence using mature Compustat firms, presumably closer to industry steady state conditions, this assumption seems reasonable.
} 
boundaries in the United States date back to the nineteenth century. Although there was some deregulation of branching restrictions in the 1930s, most states either prohibited branching altogether (the "unit banking" states) or limited branching until the 1970s, when only twelve states allowed unrestricted statewide branching. Between 1970 and 1994, however, 38 states deregulated their restrictions on branching (see Jayaratne and Strahan, 1996, Kroszner and Strahan, 1999 and Stiroh and Strahan, 2003).

In addition to facing restrictions on in-state branching, the Douglas Amendment to the 1956 Bank Holding Company Act prohibited a bank holding company from acquiring banks outside the state where it was headquartered unless the target bank's state permitted such acquisitions. Since no state allowed such transactions in 1956, the amendment effectively barred interstate banking organizations. Starting in the earlier 1980s, many states began to enter regional or national reciprocal arrangements whereby their banks could be bought by any other state in the arrangement. This history presents us with a convenient way to test how industry structure in non-financial sectors has been affected by the increased competition (real and potential) in banking that followed state-level deregulation. ${ }^{17}$

We capture the effects of each type of deregulation by including an indicator equal to one after a state permits branching by means of merger and acquisition within its borders, and another indicator equal to one after a state permits interstate banking (that is, after a state allows bank holding companies from other states to buy their banks). ${ }^{18}$ The two types of deregulation

\footnotetext{
${ }^{17}$ Deregulation of restrictions on bank expansion, both within and across states, has been shown to improve bank efficiency, to enhance corporate control, and to limit market power. See Jayaratne and Strahan (1998).

${ }^{18}$ Most states first permit banks to branch by buying existing branches in new markets or by purchasing whole banks and then creating branches out of the purchased bank's offices. Then, states typically open up their markets to unrestricted branching in which banks may open new branches anywhere in the state.
} 
are somewhat distinct in their effects. Deregulation of restrictions on branching reduces entry barriers into new markets and also enhances the corporate takeover market by making it easier for banks to gain control over other bank's assets. With full branching deregulation, a bank may enter a new market, either by buying existing branches or by opening new branches. Also, the cost of acquiring another bank is reduced because an acquiring bank may merge the target bank's operation into its existing franchise. By reducing entry barriers, branching deregulation constrains banks' ability to exploit market power. Interstate banking deregulation, however, only affects who can own bank assets. Prior to deregulation, only bank holding companies located within a state may buy banks chartered in that state, while, after deregulation, bank holding companies operating in other states may do so.

In addition to looking at changes in competition induced by deregulation of the industry, we also include a direct measure of local market concentration, equal to the deposit HerfindahlHirschmann Index (HHI). The HHI is calculated as the deposit-weighted average of the HHI indexes of the Metropolitan Statistical Areas (MSAs) in a state/year. The Herfindahl index for each local market is defined as the sum of squared market shares, where market shares are based on branch-level deposit data from the FDIC's Summary of Deposits dataset. ${ }^{19}$ So, for example, if a bank owned 10 branches within an MSA, this bank's market share would equal the sum of all of its deposits in those 10 branches, divided by the total deposits held in by all bank branches within that market. For a market with a single bank owning all of the branches, the HHI would equal one, whereas in a perfectly atomistic market the HHI would approach zero.

\footnotetext{
19 The deposit HHI is the standard tool used in antitrust oversight of bank mergers. Local markets (usually MSAs or non-MSA counties) with HHI below 0.18 are deemed to be served by enough banks to assume that conditions are competitive. For localities with HHI above 0.18, antitrust concerns by the Federal Reserve and the Department of
} 
The history of U.S. banking deregulation defines the lower and upper bound of our sample period. Our panel data starts in 1977, the beginning of the period of dramatic state-level deregulation. We end the sample in 1994, when deregulation of restrictions on banks' ability to expand across local markets was completed with passage of the Riegle-Neal Interstate Banking and Branching Efficiency Act. After 1994, it becomes increasingly less plausible to view markets in banking as local, both because of the completion of deregulation and because the advent of new technologies in bank lending began allowing banks to lend to borrowers not physically close to their bank. For example, Petersen and Rajan (2002) show that banks during the 1990s are much more likely to lend over long geographic distances than they were in the 1970s. Also, banks began to operate branches across state lines for the first time in $1995 .{ }^{20}$

\section{Results}

\section{A. Difference-in-differences estimates}

As noted above, our identification strategy is to emphasize the differential effects of bank competition across bank dependent and non-dependent sectors. Table IV illustrates this strategy based on a simple 'difference-in-differences' estimate of the effect of changes in concentration and regulation on establishment size. We simply average the data across four groups: sectors with high and low external financial dependence and markets/years with high and low bank concentration (Panel A) or with tight and relaxed bank regulation (Panel B). Establishment size

Justice are sometimes raised. See Berger, Demsetz and Strahan (1999) for an overview of bank mergers and antitrust policy.

${ }^{20}$ For example, NationsBank consolidated banks from several other states into its primary North Carolina bank (NationBank NC N.A.), leading to an increase of this bank's assets from \$31 billion in 1994 to \$79 billion in 1995. 
is consistently higher among sectors with high external financial dependence (the "treatment" group) than sectors with low external financial dependence (the "control" group). But our estimate depends on the relative response of the two groups to changes in competition. For example, in the treatment group establishment size is 11 employees higher in banking markets with low concentration (HHI below 0.14 ) compared to highly concentrated markets (HHI above 0.24). But establishment size in the control group is 20 employees higher in the less concentrated banking markets. Thus, the estimated effect of decreased banking concentration (increased competition) is a decline of nine employees on average: 11-20 $=-9$.

\section{TABLE IV ABOUT HERE}

Panel A thus illustrates the importance of our identification strategy; by focusing on the direct effect of concentration, one might conclude that raising banking competitiveness leads to larger firms. Establishment size, however, is negatively correlated with banking market concentration for reasons having nothing to do with banking competition. Rural and relatively sparsely populated states tend to have fewer banks and hence higher measures of banking concentration, and these states also tend to have smaller establishments on average. Comparing the response of the two industry sectors removes these state effects from the difference-indifferences estimate. In the regressions below, state differences are removed by including the full set of state/year fixed effects.

In Panel B, we consider varying the regulatory status of banking markets. Moving from fully regulated (no branching or interstate banking) to fully deregulated (branching and interstate banking permitted), average establishment size declines by four employees in the control group. In contrast, size falls by 16 employees in the treatment group. In this example, then, our 
difference-in-differences estimate of the effect of deregulation would equal a decline of 12 employees: $-16-(-4)=-12$. These simple mean comparisons illustrate the identification strategy embedded in our regressions (see equation 1), which we turn to next.

\section{B. Regression results for size and number of establishments}

Table $\mathrm{V}$ reports our regression results for the log of the number of establishments and the $\log$ of establishment size (average employees per establishment). The first two columns report the results using an indicator variable to separate firms into two groups: those with positive external financial dependence, and those with negative dependence. These results are most closely related to the difference-in-differences calculations in Table IV because we can think about a treatment group response versus a control group response. Columns 3 and 4 report the interaction effects of the continuous measure of external financial dependence for the mature Compustat firms with our three banking competition measures, and the last two columns are based on interacting the loans/assets ratio for small firms with bank competition. As noted above, we include a full set of industry/year and state/year fixed effects; these capture all of the direct effects of external financial dependence (an industry characteristic) and bank competition (a market characteristic) on establishment size. Thus, only the coefficients on the interaction terms are identified in these models.

\section{TABLE V ABOUT HERE}

All six specifications in Table $\mathrm{V}$ support the idea that increased bank competition through lower banking concentration is associated with greater entry (i.e. more total establishments) and a smaller average establishment size. While somewhat less robust across our measures of external financial dependence, the results also suggest that deregulation, particularly relaxation 
of restrictions on interstate banking, come with an increase in the number of firms and a reduction in size. This finding mirrors Black and Strahan (2002), who find the interstate banking reform was followed by an increase in the formation of new incorporations. ${ }^{21}$

In Table VI, we use the coefficients from above (Table V) to assess the economic importance of increased banking competition on the number and size of establishments. We report effects similar to the difference-in-differences of Table IV, but now measure percentage changes rather than absolute changes since both dependent variables are measured in logs. For example, we report the percentage change in the number and size of establishments stemming from a move from full regulation (no branching or interstate banking) to full deregulation (branching and interstate banking permitted) for financially dependent industries relative to less dependent industries. And, we measure the effect of moving banking concentration from the $75^{\text {th }}$ to the $25^{\text {th }}$ percentile of its distribution (HHI changes from 0.24 to 0.14 ). These percentage changes allow a simple way to assess the economic significance of the results.

\section{TABLE VI ABOUT HERE}

Columns 1 and 2 report economic effects for our preferred measure of external financial dependence, which simply uses an indicator variable to separate sectors into low and high external financial dependence. These results suggest that deregulation, and the associated increase in banking competition, increased the number of establishments by 11.6 percent in the

\footnotetext{
${ }^{21} \mathrm{We}$ have also tested for a structural break in the link from our three bank competition measures to industry structure by interacting each measure with a post-1985 indicator variable (1985 is the midpoint of our sample). This test is motivated by the increasing use of information technology in the latter half of the sample, which may have reduced the importance of relationships in bank lending and thus altered the role of market power in shaping industry structure. We find, however, no such break; these coefficients are stable over time. The F-test for the structural break equals $1.17(\mathrm{p}$-value $=0.31)$ for the model based on the number of establishments, and 1.32 (p-value $=0.26$ ) for the model based on average establishment size. A plausible explanation for this is that the widespread
} 
dependent sectors relative to non-dependent sectors, and reduced relative establishment size by 12.3 percent. Reducing banking concentration from 0.24 to 0.14 increases the number of firms by $4.6 \%$ and reduces average firm size by $9.3 \%$.

The next four columns repeat this exercise using the two alternate measures of external financial dependence. Dependence equals the level of external funds needed to finance investment (columns 3 and 4) or the median loans/assets ratio for small firms represented in the 1998 SSBF (columns 5 and 6). Since these are continuous variables, we report the relative effects of increased banking competition comparing industries at the $75^{\text {th }}$ percentile of the external financial dependence (loan/assets) distribution, with its effects on industries at the $25^{\text {th }}$ percentile of the distribution. For example, we are comparing how bank competition affects a financially dependent industry like Petroleum and coal products (SIC=29) with one like Food and Kindred Product (SIC=20). As noted above in Table II, the level of external financial dependence is skewed by three "cash cow" industries generating substantially more funds than they need (Leather, Tobacco, and Apparel). Nevertheless, the economic significance of a decrease in banking concentration is only slightly smaller than what comes from the indicator variable models; the number of establishments increases by $3.6 \%$ with lower bank concentration and size declines by $6.9 \%$. In contrast, the effects of deregulation are considerably smaller in these models. However, if we reduce the influence of the three outlier industries by setting their external financial dependence to -0.24 (the level of external financial dependence for the fourth least dependent sector), the economic significance moves much closer to what comes out of the indicator variable specifications. Moving from full regulation to full deregulation now increases 
the number of establishments by $6.2 \%$ and decreases average size by $8.2 \%$ (figures not reported in the table).

In the last two columns, economic significance is somewhat smaller for reductions in banking concentration than what comes from the indicator variable model. For deregulation, the effects are larger based on establishment size but smaller based on the number of establishments. It is worth repeating, however, that we view these results as robustness tests only because the use of external bank finance (loans) by small firms may reflect to some extent supply-side constraints stemming from the absence of banking competition.

\section{Characterizing changes in the establishment size distribution}

The results so far indicate that improvements in bank competitive conditions lead to more establishments and to a smaller average establishment size. These two changes could reflect entry by very small establishments; if so, then we would expect an increase in mass at the smallest end of the size distribution, and declines in mass elsewhere in the distribution. If better bank competition also helps existing small firms grow (due to an increased supply of financial resources), then we ought to see a greater proportion not only of the smallest but also of midsized establishments as well. Moreover, testing for shifts in the whole size distribution allows us to compare how the shares of small and mid-sized (presumably bank dependent) establishments behave relative to another sort of 'control' group, namely the share of the very largest establishments. These establishments (those with 1,000 or more employees) should not be affected by banking conditions because very large firms have access to nationwide (and competitive) securities markets. Thus, their fortunes should not vary with local credit conditions.

sample period. 
To explore these issues, we now report the effects of changes in bank competition on the share of establishments at different points along the employment-size distribution (Tables 7 and 8). Each column in the two tables corresponds to the proportion of establishments in a given size bin. For example, in column one the dependent variable is based on the share of establishments with fewer than five employees, in column two the share of establishments with five to 19 employees, etc. To mitigate the possibility of heteroskedasticity, in Table VII we transform these proportions using the logit function (i.e. the $\log \{P /(1-P)\}$, where $P$ equals the proportion of establishments in a given size bin). Note that because we disaggregate the data both by industry and state, there are a large number of observations with zero establishments in the over1,000 category. Because the logit model is not feasible for this group, we also report the results based on the raw proportions (Table VIII). These coefficients are also easier to interpret than logit coefficients.

\section{TABLE VII ABOUT HERE}

The results in Table VII are again consistent with the earlier finding that increases in banking competition lead to increases in the importance of small firms. That is, the size distribution of establishments shifts to the left (toward small establishments) as the banking industry becomes increasingly competitive. Reduced bank concentration increases the share of firms in the first three size bins: fewer than five employees, five to 19 employees, and 20 to 99 employees (i.e. the sign of the coefficient on local-market HHI is negative). The effect of concentration is greatest for the smallest, and presumably most bank dependent, size group. But the increase in the share of firms in the next two size bins indicates that small incumbent firms also benefit from greater banking competition (assuming that most entry occurs among the 
smallest establishment). Conversely, we observe a decline in the share of firms in the 100 to 999 employee-size group with decreases in banking concentration (i.e. a positive coefficient in the HHI).

In contrast to concentration, bank deregulation, particularly interstate banking reform, seems to be positively related to the share of firms in the second and third smallest categories, whereas there is no significant effect on the smallest establishments. This increase in small establishments again occurs at the expense of firms with 100 to 999 employees. Interstate banking deregulation allows entry by large out-of-state banking organizations, which may explain why this reform seems to aid the medium-sized establishments more than the smallest establishments. Branching reform allows banks to expand, but only within state boundaries (at least until 1995, when inter-state branching began). Thus, branching reform enhances competition but has much less of an impact on the presence of large banks. Its effects seem most concentrated on the smallest establishments. (Branching deregulation, while not significant in Table VII, is positive and significant for the smallest bin in Table VIII.)

\section{TABLE VIII ABOUT HERE}

Table VIII reports the results based on the raw share of establishment in each size bin. Here, we lose some statistical significance but gain a convenient way to assess the economic magnitudes of the results. For example, moving bank concentration from the $75^{\text {th }}$ to the $25^{\text {th }}$ percentile (a decline of 0.1) comes with an increase in the share of establishments in the smallest size bin of 0.83 percentage points, or a three percent increase in the unconditional mean (31 percent). The same decline in concentration comes with an increase of 0.15 percentage points in the share in the second smallest size bin, and an increase of 0.40 percentage points in the third 
smallest bin. The increased presence of small firms seems to come again from firms in the 100 to 999 employee group. According to Table VIII, this share declines by about 1.5 percentage points, which is about 12 percent of the unconditional mean (13 percent).

Table VIII also lets us test whether another 'control' group - the largest establishments are affected by changes in local banking competition. In fact, we find no significant change in the relative importance of the very largest establishments, those with more than 1,000 employees. This lack of reaction to changes in banking competition makes sense because the largest establishments are likely to be part of firms with access to nationwide securities markets. Hence, their access to financial resources does not depend on conditions in local banking markets.

As a final test, we have considered whether regulatory changes altered the effects of banking concentration on the establishment size distribution. Black and Strahan (2002) argue that after states opened up their local banking markets to outside entry, the effects of concentration ought to have been mitigated by the threat of entry. That is, banking concentration no longer signals market power when barriers to entry from regulations have been eliminated. And, in fact, they find that the effect of concentration on the rate of creation of new incorporations does fall significantly with deregulation. We have run similar tests using our measures of the size distribution and the number of establishments. Specifically, we add variables interacting the deregulation variables with our measure of bank concentration (and the industry external financial dependence measures). In these regressions (not reported), we do estimate a generally positive coefficient (six out of eight) on these interaction terms, suggesting 
that the effects of concentration on the size distribution may be attenuated by regulatory reform. These additional interaction effects, however, are not statistically significant.

\section{Conclusions}

We have found that more vigorous competition in local U.S. banking markets - lower MSA-level bank concentration and looser state-level restrictions on bank entry - reduces the size of the typical establishment. Better bank competition also increases the share of establishments in the smallest size group, and increases the total number of establishments. Significantly, changes in bank competition have no effect on the largest establishments, which makes sense given their access to financial resources in the commercial paper, corporate bond and equity markets.

Theory does not paint a clear picture about how competition in banking ought to affect the firm-size distribution, but the empirical work does. Comparing industry structure across local markets within the U.S., or comparing structure across a large number of countries (both developed and developing), one reaches the same conclusion. Our empirical evidence is consistent with the idea that banks with market power erect an important financial barrier to entry to the detrimant of the entrepreneurial sector of the economy, perhaps in part to protect the profitability of their existing borrowers. The evidence thus indicates that bank competition has a significant impact on important structural characteristics of sectors of production. Moreover, it indicates that such impact is not uniform across firms, but rather that depending on the degree of bank competition some firms may benefit while others may lose. This is an important insight updating the conventional wisdom that bank competition is either good or bad overall. 
The policy implications associated with this issue are especially relevant. Banking market structure is a traditional policy variable whose control regulators across countries and over time often attempt to influence, although sometimes in conflicting ways. For example, in the United States bank mergers have sometimes been altered to avoid excessive concentration in local markets. At the same time, however, until the 1980s many states protected their banks from competition through branching and interstate banking restrictions. Similar restraints on competition have been common elsewhere; for example, many countries continue to protect their banks from foreign entry. One can well understand why political forces lead to tight restraints on banking competition if both incumbent banks and incumbent firms benefit from the restraints. In fact, Rajan and Zingales (2003) use historical evidence to argue very broadly that incumbent firms often fought hardest to prevent financial openness, sometimes leading to long-term declines in a country's growth prospects. 


\section{References}

Bhattacharya, Sudipto and Gabriella Chiesa, 1995, Proprietary Information, Financial Intermediation, and Research Incentives, Journal of Financial Intermediation, 4, 4, 328-57.

Beck, Thorsten, Asli Demirguc-Kunt and Vojislav Maksimovic, 2004, Bank Competition and Access to Finance: International Evidence, Journal of Money, Credit and Banking, 36, 3, 627-48.

Berger, Allen N., Rebecca S. Demsetz and Philip E. Strahan, 1999, The Consolidation of the Financial Services Industry: Cause, Consequences and Implications for the Future, Journal of Banking and Finance 23, 135-94.

Bertrand, Marianne, Antoinette Schoar and David Thesmar, 2004, Banking Deregulation and Industry Structure: Evidence from the French Banking Reforms of 1985, C.E.P.R. Discussion Papers, 4488.

Bitler, Marianne P., Alicia M. Robb, and John D. Wolken, 2001, Financial Services Used by Small Businesses: Evidence from the 1998 Survey of Small Business Finance, Federal Reserve Bulletin, 183-205.

Black, Sandra E. and Philip E. Strahan, 2002, Entrepreneurship and Bank Credit Availability, Journal of Finance 57, 6, 2807-33.

Bonaccorsi di Patti, Emilia and Giovanni Dell'Ariccia, 2004, Bank Competition and Firm Creation, Journal of Money, Credit and Banking, 36, 2, 225-51.

Brander, James and Tracy Lewis, 1986, Oligopoly and Financial Structure: The Limited Liability Effect, The American Economic Review, 76, 5, 956-970.

Campbell, Jeffrey R., and Hugo A. Hopenhayn, 2002, Market Size Matters, NBER Working Papers: 9113.

Cetorelli, Nicola, 2001, Does Bank Concentration Lead to Concentration in Industrial Sectors? Federal Reserve Bank of Chicago, Working Paper 01-01.

Cetorelli, Nicola, 2003, Life-Cycle Dynamics in Industrial Sectors. The Role of Banking Market Structure, Quarterly Review, Federal Reserve Bank of St. Louis, 85, 4, 135-47.

Cetorelli, Nicola, 2004, Real Effects of Bank Competition, Journal of Money, Credit and Banking, 36, 3, 543-58.

Cetorelli, Nicola and Michele Gambera, 2001, Bank Structure, Financial Dependence and Growth: International Evidence from Industry Data, Journal of Finance, 56, 2, 617-48. 
Cestone, Giacinta and Lucy White, 2003, Anti-Competitive Financial Contracting: The Design of Financial Claims, Journal of Finance, 58, 5, 2109-42.

Chevalier, Judith, 1995, Capital Structure and Product Market Competition: Empirical Evidence from the Supermarket Industry, American Economic Review, 85, 3, 415-35.

Demirguc-Kunt, Asli and Vojislav Maksimovic, 1998, Law, Finance and Firm Growth, Journal of Finance 53, 2107-37.

Evans, David S., 1987, The Relationship Between Firm Growth, Size, and Age: Estimates for 100 Manufacturing Industries (in Competition in the Long Run), Journal of Industrial Economics, 35, 4, 567-581.

Goldsmith, Raymond, Financial Structure and Development, (New Haven: Yale University Press, 1969).

Gurley, John G. and Edward S. Shaw, 1955, Financial Aspects of Economic Development, American Economic Review, 45, 515-38.

Hellmann, Thomas and Marco Da Rin, 2002 , Banks as Catalysts for Industrialization, Journal of Financial Intermediation, 11, 366-397.

Hopenhayn, Hugo A., 1992, Entry, Exit, and Firm Dynamics in Long Run Equilibrium, Econometrica, 60, 5, 1127-1150.

Jayaratne, Jith and Philip E. Strahan, 1996, The Finance-Growth Nexus: Evidence from Bank Branch Deregulation, Quarterly Journal of Economics, 101, 639-70.

Jayaratne, Jith and Philip E. Strahan, 1998, Entry Restrictions, Industry Evolution and Dynamic Efficiency: Evidence from Commercial Banking, Journal of Law and Economics 41, 239-74.

Jovanovic, Boyan, 1982, Selection and Evolution of Industry, Econometrica, 50, 3, 649-670.

King, Robert and Ross Levine, 1993a, Finance, Entrepreneurship and Growth, Journal of Monetary Economics, 32, 513-542.

King, Robert and Ross Levine, 1993b, Finance and Growth: Schumpeter Might Be Right, Quarterly Journal of Economics, 108, 717-738.

Klepper, Steven, 1996, Entry, Exit, Growth, and Innovation over the Product Life Cycle, American Economic Review, 86, 562-583.

Kovenock and Phillips, 1995, Capital Structure and Product Market Rivalry: How do we Reconcile Theory and Evidence? American Economic Review 85, 408-408. 
Kroszner, Randall S. and Philip E. Strahan, 1999, What Drives Deregulation? Economics and Politics of the Relaxation of Bank Branching Restrictions, Quarterly Journal of Economics 114, 4, 1437-67.

Kumar, Krishna, Raghuram G. Rajan and Luigi Zingales, 2001, What Determines Firm Size? NBER Working paper no. 7208.

Laporta, Rafael, Florencio Lopez-de-Silanes and Andrei Shleifer, 2002, Government Ownership of Banks, Journal of Finance, 57, 1, 265-301.

Levine, Ross, 1999, Law, Finance and Economic Growth, Journal of Financial Intermediation, 8, $1-2,8-35$

Levine Ross, Norman Loayza, and Thorsten Beck, 2000, Financial intermediation and growth: Causality and Causes, Journal of Monetary Economics 46, 1, 31-77.

Levine, Ross and Sara Zervos, 1998, Stock Markets, Banks and Economic Growth, American Economic Review 88, 3, 537-58.

Lucas, Robert E., 1978, On the Size Distribution of Firms, Bell Journal of Economics 9, 2, 50823.

Maksimovic, Vojislav, 1988, Capital Structure in a Repeated Oligopoly, Rand Journal of Economics, 389-407.

Maurer, Noel and Stephen Haber, 2003, Bank Concentration, Related Lending, and Economic Performance: Evidence from Mexico. Mimeo, Stanford University.

Mayer, Colin, 1988, New Issues In Corporate Finance. European Economic Review, 32, 5, 1167 83.

McKinnon, Ronald, Money and Capital in Economic Development, (Washington, DC: Brookings Institution, 1973).

Petersen, Mitchell A. and Raghuram G. Rajan, 1995, The Effect of Credit Market Competition on Lending Relationships, Quarterly Journal of Economics 110, 407-43.

Petersen, Mitchell A. and Raghuram G. Rajan, 2002, Does Distance Still Matter? The Information Revolution in Small Business Lending, Journal of Finance, 57, 6, 2533-70.

Rajan, Raghuram G. and Luigi Zingales, 1998, Financial Dependence and Growth, American Economic Review 88, 559-87. 
Rajan, Raghuram G. and Luigi Zingales, 2003, Saving Capitalism from the Capitalists, Crown Business Division of Random House.

Schumpeter, Joseph A. 1912. Theorie der Wirtschaftlichen Entwicklung. Leipzig: Dunker \& Humblot, (The Theory of Economic Development, translated by Redvers Opie. Cambridge, MA: Harvard University Press, 1934.)

Spagnolo, Giancarlo, 2000, Debt as a (Credible) Collusive Device, Stockholm School of Econommics, Working paper, 243.

Stiroh, Kevin and Philip E. Strahan, 2003, Competitive Dynamics of Deregulation: Evidence from U.S. Banking, Journal of Money, Credit and Banking, 35, 5, 801-28. 


\section{Table I}

\section{Summary Statistics}

This table reports summary statistics for data used in our panel regressions. The unit of observation varies at the state-industry-year level. Data on establishments are from the County Business Patterns, 1977-1994. The HHI, our measure of concentration, is built up from HHIs at the city level (Metropolitan Statistical Area). By city, we construct the sum of squared share of deposits for each banking company. We then average this concentration measure across all MSAs within the state, weighted by total deposits in each MSA (source: FDIC Summary of Deposits). The post branching deregulation indicator equals 1 during all years in which a state permits instate branching; the post interstate banking deregulation indicator equals 1 during all years in which a state permits outof-state banking companies to buy banks headquartered in the state. For a detailed discussion of the banking deregulation, see Kroszner and Strahan (1999).

\begin{tabular}{lcc}
\hline & Mean & $\begin{array}{c}\text { Standard } \\
\text { Deviation }\end{array}$ \\
\hline Establishments Per Capita & 0.07 & 0.09 \\
Share of Establishments with < 5 Employees & 0.31 & 0.15 \\
Share of Establishments with 5 to 19 Employees & 0.31 & 0.12 \\
Share of Establishments with 20 to 99 Employees & 0.24 & 0.11 \\
Share of Establishments with 100 to 999 Employees & 0.13 & 0.12 \\
Share of Establishments with more than 1,000 Employees & 0.01 & 0.02 \\
Average Establishment Size (employees per establishment) & 69 & 83 \\
HHI (sum of squared local-market deposit share) & 0.19 & 0.07 \\
Post Branching Deregulation Indicator & 0.60 & - \\
Post Interstate Banking Deregulation Indicator & 0.45 & - \\
\hline
\end{tabular}




\section{Table II}

\section{External Financial Dependence for Manufacturing Sectors}

External financial dependence equals the proportion of capital expenditures financed with external funds. A negative value indicates that firms have free cash flow, whereas a positive value indicates firms must issue debt or equity to finance their investment. The figures represent the median value for Compustat firms in each industry sector over the 1980 to 1997 period. Mature firms are those that have been on Compustat for 10 years or more. The rows are sorted by the external finance measure for mature firms, which is our baseline measure of an industry's long-term financing needs. The loans/assets ratio is the median ratio of loans to assets for small firms from the Federal Reserve 1998 Survey of Small Business Finance.

Panel A: Medians by Industry Sector (2-digit SIC)
Median

Loans/Assets for 1998 SSBF Firms
External Financial

Dependence for Mature Compustat Firms

\begin{tabular}{lcc}
\hline Leather and leather products (31) & 0.04 & -0.96 \\
Tobacco manufactures (21) & $\mathrm{N} / \mathrm{A}$ & -0.92 \\
Apparel and other textiles (23) & 0.13 & -0.61 \\
Food and kindred products (20) & 0.12 & -0.24 \\
Fabricated metal products (34) & 0.27 & -0.24 \\
Furniture and fixtures (25) & 0.36 & -0.23 \\
Stone, clay, glass, and concrete products (32) & 0.31 & -0.20 \\
Miscellaneous manufacturing (39) & 0.28 & -0.20 \\
Printing and publishing (27) & 0.33 & -0.07 \\
Instruments and related products (38) & 0.29 & -0.04 \\
Transportation equipment (37) & 0.06 & 0.01 \\
Industrial machinery and equipment (35) & 0.21 & 0.01 \\
Primary metal industries (33) & 0.31 & 0.03 \\
Lumber and wood products (24) & 0.49 & 0.04 \\
Rubber and plastic products (30) & 0.30 & 0.04 \\
Paper and allied products (26) & 0.37 & 0.06 \\
Petroleum and coal products (29) & 0.60 & 0.09 \\
Textile mill products (22) & 0.47 & 0.10 \\
Electrical and electronic equipment (36) & 0.14 & 0.22 \\
Chemicals and allied products (28) & 0.33 & 0.28 \\
\hline Median & 0.30 & 0 \\
\hline Correlation between the two: & & \\
\hline
\end{tabular}




\section{Table III}

\section{Median Industry-Level Investment and Financing Characteristics for Mature Compustat Firms, by External financial dependence}

This table reports the average of the industry-level median characteristics for mature Compustat firms (i.e. firms in Compustat for at least 10 years). External financial dependence equals the share of capital expenditures financed with external funds; equity finance equals the share of capital expenditures financed by issuance of new equity (negative values indicate that cash is paid out to equity holders); debt finance equals the share of capital expenditures financed by new borrowing (negative values indicates reductions in outstanding debt). Real sales are expressed in 1997 dollars, based in the Consumer Price Index.

\begin{tabular}{cc} 
High external financial & Low external \\
dependence for & financial \\
Mature Firms & dependence for \\
& Mature Firms \\
\hline
\end{tabular}

External Financial Dependence

0.05

$-0.23$

Equity Finance

0

0

Debt Finance

0.05

$-0.23$

Capital expenditures / Property, plant \& equipment

0.19

0.19

Ratio of book value of equity to market value of equity

0.66

0.68

Median Real Sales (1997 Millions of Dollars)

$\$ 273$

$\$ 216$ 


\section{Table IV}

\section{Comparison of Mean Establishment Size For Competitive Versus Non-competitive Banking Markets}

This table reports a simple difference-in-differences estimate of the effects on average establishment size of moving from a regulated to an unregulated market, or from a concentrated to an unconcentrated market. Concentrated markets have an HHI in the first quartile of the distribution (HHI > 0.24); unconcentrated markets have an HHI in the top quartile (HHI < 0.14). Regulated markets allow neither branching nor interstate banking; deregulated markets permit both. The "treatment" group is represented by industries with above-median needs for external finance. The "control" group is represented by industries with below-median needs for external finance. A '*' denotes statistical significance at the $5 \%$ level; a '**' denotes significance at $1 \%$, based on a simple t-test.

(1) "Treatment" group

(2) "Control” group

(3) "Treatment" group

(4) "Control” group
Panel A: Banking Markets with

Low

Concentration

82 Concentration

61

41

20

$\begin{array}{ccc}21 & 30 \\ & \text { Difference-in-Differences }= & \mathbf{- 9} * *\end{array}$

Panel B: Banking Markets with Deregulated Banking

Markets Regulated Banking

\begin{tabular}{ccc} 
Markets & Markets & Difference \\
\hline 74 & 90 & -16
\end{tabular}

52

56

$-4$ 


\section{Table V}

\section{Regression of Log of Establishment Size and Log of Number of Establishments on Bank Competition Variables}

Each column in this table reports statistics from a fixed effects regression, where the dependent variable is the log of the total number of establishments per capita (columns labeled "number") or the log of average number of workers per establishment (columns labeled "size"). Data on establishments are from the County Business Patterns, 19771994. The terms of interaction are based on external financial dependence for mature Compustat firms and the ratio of total loans to assets for small firms based on the Federal Reserve 1998 Survey of Small Business Finance (see Table I). The HHI, our measure of concentration, is built up from HHIs at the city level (Metropolitan Statistical Area). By city, we construct the sum of squared share of deposits for each banking company. We then average this concentration measure across all MSAs within the state, weighted by total deposits in each MSA (source: FDIC Summary of Deposits). The post branching deregulation indicator equals 1 during all years in which a state permits instate branching; the post interstate banking deregulation indicator equals 1 during all years in which a state permits out-of-state banking companies to buy banks headquartered in the state. For a detailed discussion of the banking deregulation, see Kroszner and Strahan (1999). Industry share of employment equals the total employment in a given industry-state-year divided by total employment in the corresponding state-year. Absolute value of $\mathrm{t}$ statistics in parentheses; * significant at 5\%; ** significant at $1 \%$.

External Financial Dependence Measure:

Indicator $=1$ if industry has positive external dependence for mature

Level of external dependence for mature Compustat Firms
Industry median loans/assets for firms in the $1998 \mathrm{SSBF}$

\begin{tabular}{|c|c|c|c|c|c|c|}
\hline & Number & Size & Number & Size & Number & Size \\
\hline $\begin{array}{l}\text { Post-Branching * External } \\
\text { financial dependence }\end{array}$ & $\begin{array}{l}-0.006 \\
(0.30)\end{array}$ & $\begin{array}{l}-0.018 \\
(0.77)\end{array}$ & $\begin{array}{l}-0.025 \\
(0.81)\end{array}$ & $\begin{array}{c}0.120 \\
(3.22)^{* *}\end{array}$ & $\begin{array}{l}-0.095 \\
(1.40)\end{array}$ & $\begin{array}{l}-0.145 \\
(1.96)^{*}\end{array}$ \\
\hline $\begin{array}{l}\text { Post-Interstate * External } \\
\text { financial dependence }\end{array}$ & $\begin{array}{l}0.122 \\
(4.14)^{* *}\end{array}$ & $\begin{array}{l}-0.105 \\
(2.98)^{* *}\end{array}$ & $\begin{array}{l}0.039 \\
(0.77)\end{array}$ & $\begin{array}{c}-0.263 \\
(4.41)^{* *}\end{array}$ & $\begin{array}{l}0.152 \\
(1.58)\end{array}$ & $\begin{array}{c}-0.904 \\
(8.04)^{* *}\end{array}$ \\
\hline $\begin{array}{l}\text { Local-Market HHI * } \\
\text { External financial } \\
\text { dependence }\end{array}$ & $\begin{array}{c}-0.457 \\
(4.03)^{* *}\end{array}$ & $\begin{array}{c}0.934 \\
(6.88)^{* *}\end{array}$ & $\begin{array}{l}-1.245 \\
(6.56)^{* *}\end{array}$ & $\begin{array}{c}2.377 \\
(10.49)^{* *}\end{array}$ & $\begin{array}{l}-1.104 \\
(2.96)^{* *}\end{array}$ & $\begin{array}{c}3.490 \\
(8.02)^{* *}\end{array}$ \\
\hline $\begin{array}{l}\text { Industry share of } \\
\text { employment }\end{array}$ & $\begin{array}{c}7.647 \\
(94.44)^{* *}\end{array}$ & $\begin{array}{c}6.672 \\
(68.83)^{* *}\end{array}$ & $\begin{array}{c}7.652 \\
(94.57)^{* *}\end{array}$ & $\begin{array}{c}6.675 \\
(69.11)^{* *}\end{array}$ & $\begin{array}{c}7.581 \\
(101.56)^{* *}\end{array}$ & $\begin{array}{c}6.497 \\
(74.54)^{* *}\end{array}$ \\
\hline Observations & 15127 & 15127 & 15127 & 15127 & 14717 & 14717 \\
\hline Fixed Effects & \multicolumn{6}{|c|}{$\begin{array}{l}\text { State * Year } \\
\text { Industry * Year }\end{array}$} \\
\hline R-squared & 0.89 & 0.56 & 0.89 & 0.56 & 0.86 & 0.62 \\
\hline
\end{tabular}




\section{Table VI}

\section{Economic Significance of a Change in Bank Competition on Establishment Size and Number of Establishments}

This table uses the coefficients from Table $\mathrm{V}$ to compute the effect of an increase in bank competition on log number of establishments ( $\log$ of employees per establishment) on industries that are financially dependent relative to industries that are not financially dependent. In columns 1 and 2, we report the effect of bank competition on industries with above median external financial dependence for mature Compustat firms, relative to industries with below median external financial dependence. The coefficients come from columns 1 and 2 of Table V. In columns 3 and 4, we report the effect of bank competition on industries with external financial dependence for mature Compustat firms at the $75^{\text {th }}$ percentile of the distribution, relative to industries with external financial dependence at the $25^{\text {th }}$ percentile. The coefficients come from columns 3 and 4 of Table V. In columns 5 and 6 , we report the effect of bank competition on industries with loans/assets for firms in the 1998 SSBF at the $75^{\text {th }}$ percentile, relative to industries at the $25^{\text {th }}$ percentile. The coefficients come from columns 5 and 6 of Table V. As in Table IV, 'unconcentrated' markets have an HHI in the first quartile of the distribution (0.14); 'concentrated' markets have an HHI in the top quartile (0.24). Regulated markets allow neither branching nor interstate banking; deregulated markets permit both.

External Financial Dependence Measure based on:

$\begin{array}{ccc}\begin{array}{c}\text { Whether industry has } \\ \text { positive external }\end{array} & \begin{array}{c}\text { Level of external financial } \\ \text { dependence for mature } \\ \text { financial dependence for } \\ \text { mature Compustat Firms }\end{array} & \begin{array}{c}\text { Industry median } \\ \text { loans/assets for firms in } \\ \text { the 1998 SSBF }\end{array}\end{array}$

\begin{tabular}{lcccccc}
\hline & Number & Size & Number & Size & Number & Size \\
\cline { 2 - 6 } $\begin{array}{l}\text { Relative effect (in percent) } \\
\text { for a change from Fully }\end{array}$ & $11.6 \%$ & $-12.3 \%$ & $0.4 \%$ & $-4.1 \%$ & $1.2 \%$ & $-22.0 \%$ \\
$\begin{array}{l}\text { Regulated to Fully } \\
\text { Deregulated }\end{array}$ & & & & & \\
$\begin{array}{l}\text { Relative effect (in percent) } \\
\text { of a change from } \\
\begin{array}{l}\text { concentrated to } \\
\text { unconcentrated banking }\end{array} \\
\text { market. }\end{array}$ & $4.6 \%$ & $-9.3 \%$ & $3.6 \%$ & $-6.9 \%$ & $2.3 \%$ & $-7.3 \%$ \\
\end{tabular}




\section{Table VII}

\section{Regression of Logit of Size Shares on Bank Competition Variables}

This table reports coefficients from fixed effects regressions of the logit transformation of the share of establishments in different size bins in a state-industry-year. We do not report the logit for the share of establishments with more than 1,000 employees because about $3 / 4$ of the observations are zero. Data on establishments are from the County Business Patterns, 1977-1994. External financial dependence is an indicator for industries with above-median use of external finance as a fraction of capital expenditures (see Table I). The HHI, our measure of concentration, is built up from HHIs at the city level (Metropolitan Statistical Area). By city, we construct the sum of squared share of deposits for each banking company. We then average this concentration measure across all MSAs within the state, weighted by total deposits in each MSA (source: FDIC Summary of Deposits). The post branching deregulation indicator equals 1 during all years in which a state permits instate branching; the post interstate banking deregulation indicator equals 1 during all years in which a state permits outof-state banking companies to buy banks headquartered in the state. For a detailed discussion of the banking deregulation, see Kroszner and Strahan (1999). Industry share of employment equals the total employment in a given industry-state-year divided by total employment in the corresponding state-year. Absolute value of t statistics in parentheses; * significant at 5\%; ** significant at $1 \%$.

Share of Establishments with:

\begin{tabular}{|c|c|c|c|c|c|}
\hline & $\begin{array}{c}\text { Fewer than } 5 \\
\text { Employees }\end{array}$ & $\begin{array}{c}5 \text { to } 19 \\
\text { Employees }\end{array}$ & $\begin{array}{c}20 \text { to } 99 \\
\text { Employees }\end{array}$ & $\begin{array}{l}100 \text { to } 999 \\
\text { Employees }\end{array}$ & $\begin{array}{c}1,000 \text { or } \\
\text { more } \\
\text { Employees }\end{array}$ \\
\hline $\begin{array}{l}\text { Post-Branching * External } \\
\text { financial dependence } \\
\text { Indicator }\end{array}$ & $\begin{array}{l}0.063 \\
(1.57)\end{array}$ & $\begin{array}{l}-0.002 \\
(0.06)\end{array}$ & $\begin{array}{l}-0.053 \\
(1.45)\end{array}$ & $\begin{array}{l}-0.040 \\
(0.94)\end{array}$ & N/A \\
\hline $\begin{array}{l}\text { Post-Interstate * External } \\
\text { financial dependence } \\
\text { Indicator }\end{array}$ & $\begin{array}{l}-0.052 \\
(0.85)\end{array}$ & $\begin{array}{c}0.138 \\
(2.54) * *\end{array}$ & $\begin{array}{l}0.111 \\
(2.00)^{*}\end{array}$ & $\begin{array}{c}-0.271 \\
(4.18)^{* *}\end{array}$ & N/A \\
\hline $\begin{array}{l}\text { Local-Market HHI * } \\
\text { External financial } \\
\text { dependence Indicator }\end{array}$ & $\begin{array}{c}-0.929 \\
(3.91)^{* *}\end{array}$ & $\begin{array}{c}-0.492 \\
(2.35)^{* *}\end{array}$ & $\begin{array}{c}-0.575 \\
(2.69)^{* *}\end{array}$ & $\begin{array}{c}1.692 \\
(6.76)^{* *}\end{array}$ & N/A \\
\hline $\begin{array}{l}\text { Industry share of } \\
\text { employment }\end{array}$ & $\begin{array}{c}-3.283 \\
(19.36)^{* *}\end{array}$ & $\begin{array}{c}-1.355 \\
(9.05)^{* *}\end{array}$ & $\begin{array}{c}2.608 \\
(17.04)^{* *}\end{array}$ & $\begin{array}{c}7.099 \\
(39.71)^{* *}\end{array}$ & N/A \\
\hline Observations & 15127 & 15127 & 15127 & 15127 & \\
\hline Fixed Effects & & & $\begin{array}{c}\text { State * Year } \\
\text { Industry * Year }\end{array}$ & & \\
\hline R-squared & 0.21 & 0.25 & 0.21 & 0.33 & \\
\hline
\end{tabular}




\section{Table VIII}

\section{Regression of Size Shares on Bank Competition Variables}

This table reports coefficients from fixed effects regressions of the share of establishments in different size bins in a state-industry-year. Data on establishments are from the County Business Patterns, 1977-1994. External financial dependence is an indicator for industries with above-median use of external finance as a fraction of capital expenditures (see Table I). The HHI, our measure of concentration, is built up from HHIs at the city level (Metropolitan Statistical Area). By city, we construct the sum of squared share of deposits for each banking company. We then average this concentration measure across all MSAs within the state, weighted by total deposits in each MSA (source: FDIC Summary of Deposits). The post branching deregulation indicator equals 1 during all years in which a state permits instate branching; the post interstate banking deregulation indicator equals 1 during all years in which a state permits out-of-state banking companies to buy banks headquartered in the state. For a detailed discussion of the banking deregulation, see Kroszner and Strahan (1999). Industry share of employment equals the total employment in a given industry-state-year divided by total employment in the corresponding stateyear. Absolute value of $t$ statistics in parentheses; * significant at 5\%; ** significant at $1 \%$.

Share of Establishments with:

\begin{tabular}{|c|c|c|c|c|c|}
\hline & $\begin{array}{c}\text { Fewer than } 5 \\
\text { Employees }\end{array}$ & $\begin{array}{l}5 \text { to } 19 \\
\text { Employees }\end{array}$ & $\begin{array}{l}20 \text { to } 99 \\
\text { Employees }\end{array}$ & $\begin{array}{l}100 \text { to } 999 \\
\text { Employees }\end{array}$ & $\begin{array}{c}1,000 \text { or } \\
\text { more } \\
\text { Employees }\end{array}$ \\
\hline $\begin{array}{l}\text { Post-Branching * External } \\
\text { financial dependence } \\
\text { Indicator }\end{array}$ & $\begin{array}{c}0.010 \\
(2.03)^{*}\end{array}$ & $\begin{array}{l}-0.001 \\
(0.11)\end{array}$ & $\begin{array}{l}-0.007 \\
(1.83)\end{array}$ & $\begin{array}{l}-0.002 \\
(0.49)\end{array}$ & $\begin{array}{l}-0.001 \\
(0.92)\end{array}$ \\
\hline $\begin{array}{l}\text { Post-Interstate * External } \\
\text { financial dependence } \\
\text { Indicator }\end{array}$ & $\begin{array}{l}-0.012 \\
(1.72)\end{array}$ & $\begin{array}{c}0.019 \\
(3.10)^{* *}\end{array}$ & $\begin{array}{l}0.009 \\
(1.71)\end{array}$ & $\begin{array}{c}-0.018 \\
(3.01)^{* *}\end{array}$ & $\begin{array}{l}0.001 \\
(0.99)\end{array}$ \\
\hline $\begin{array}{l}\text { Local-Market HHI * } \\
\text { External financial } \\
\text { dependence Indicator }\end{array}$ & $\begin{array}{c}-0.083 \\
(2.96)^{* *}\end{array}$ & $\begin{array}{l}-0.015 \\
(0.64)\end{array}$ & $\begin{array}{l}-0.040 \\
(1.84)\end{array}$ & $\begin{array}{c}0.146 \\
(6.44)^{* *}\end{array}$ & $\begin{array}{l}-0.007 \\
(1.59)\end{array}$ \\
\hline $\begin{array}{l}\text { Industry share of } \\
\text { employment }\end{array}$ & $\begin{array}{c}-0.609 \\
(30.58)^{* *}\end{array}$ & $\begin{array}{c}-0.323 \\
(18.74)^{* *}\end{array}$ & $\begin{array}{c}0.222 \\
(14.46)^{* *}\end{array}$ & $\begin{array}{c}0.610 \\
(37.71)^{* *}\end{array}$ & $\begin{array}{c}0.100 \\
(32.98)^{* *}\end{array}$ \\
\hline Observations & 15127 & 15127 & 15127 & 15127 & 15127 \\
\hline Fixed Effects & & & $\begin{array}{c}\text { State * Year } \\
\text { Industry * Year }\end{array}$ & & \\
\hline R-squared & 0.37 & 0.26 & 0.29 & 0.41 & 0.23 \\
\hline
\end{tabular}

